\title{
Risk areas for hepatitis A, B and C in the municipality of Maringá, Paraná State, Brazil 2007-2010
}

\author{
Valéria Miranda Avanzi, ${ }^{1}$ Udelysses Janete Veltrini Fonzar, ${ }^{2}$ Eraldo Schunk Silva, ${ }^{3}$ \\ Jorge Juarez Vieira Teixeira, ${ }^{4}$ Dennis Armando Bertolini ${ }^{4}$
}

\author{
${ }^{1}$ Postgraduate Program in Health Sciences, State University of Maringá; ${ }^{2}$ Municipal Health Department of \\ Maringá; ${ }^{3}$ Department of Statistics, State University of Maringá; ${ }^{4}$ Department of Clinical Analysis and \\ Biomedicine, Health Sciences Center, State University of Maringá, Maringá, Paraná, Brazil
}

\begin{abstract}
Viral hepatitis is a major public health problem in Brazil and worldwide. We retrospectively analyzed 338 cases of hepatitis A, B and C in Maringá, Paraná State from 2007 through 2010. The hepatitis A virus was present in $5.6 \%$ of the cases, hepatitis B in $44.7 \%$ and hepatitis $C$ in $49.7 \%$. Most of the patients affected were male $(55.3 \%)$, white $(79.6 \%)$ and had some primary education $(42.9 \%)$. Of the 338 cases analyzed, $13.0 \%$ had comorbidities. The cases were concentrated in large-population census zones, but it was concluded that the spatial distribution of viral hepatitis in Maringá occurred randomly rather than show any regular pattern.
\end{abstract}

Correspondence: Dennis Armando Bertolini, Department of Clinical Analysis and Biomedicine, Health Sciences Center, Colombo Avenue, 5790, State University of Maringá, Maringá, Paraná, Brazil.

Tel.: +55.44.3261.4495 - Fax: +55.44.3263.1387.

E-mail: dabertolini@uem.br

Key words: Demography; Human viral hepatitis; Epidemiology; Health education; Health surveys; Co-infection; Brazil.

Contributions: the authors contributed equally.

Conflict of interest: the authors declare no potential conflict of interest.

Funding: none.

Ethical approval: the study was approved by the Standing Committee on Ethics in Research Involving Human Beings of the State University of Maringá (Number 486/2010).

Received for publication: 26 October 2017

Revision received: 30 January 2018.

Accepted for publication: 3 February 2018.

(C) Copyright V.M. Avanzi et al., 2018

Licensee PAGEPress, Italy

Geospatial Health 2018; 13:607

doi:10.4081/gh.2018.607

This article is distributed under the terms of the Creative Commons Attribution Noncommercial License (CC BY-NC 4.0) which permits any noncommercial use, distribution, and reproduction in any medium, provided the original author(s) and source are credited.

\section{Introduction}

Viral hepatitis are one of the most common group of infectious diseases in the world and also a particularly important publichealth problem because of the challenges involved in its control (Ferreira et al., 2004). About two billion people worldwide have had contact with one of the hepatitis viruses and globally, in 2015, an estimated 257 million people were living with chronic HBV infections, 71 million of thosewith chronic hepatitis C (HCV) infection (WHO, 2017). In Brazil, the number of patients with viral hepatitis have been decreased, except for HCV, and the number of infected patients varies in different states and municipalities (Brazil, 2017). Evaluation of the magnitude of viral hepatitis is especially difficult in a country such as Brazil, which has a population of about 208 million in a vast territory of about $8,500,000$ $\mathrm{km}^{2}$ (IBGE, 2017). Surveillance of viral hepatitis in Brazil uses a system based on information from notification and epidemiological investigation of all suspected cases and outbreaks, through the Notifiable Diseases Information System (SINAN). This system is the primary source of data on these diseases (Brazil, 2015).

Chronic hepatitis related to hepatitis B (HBV) and HCV and its complications has significant economic implications related to the loss of work hours, home and hospital treatment costs, and the high cost of liver transplants in the case of end-stage liver disease. The severe nature of the sequelae together with the economic impact justify the importance of studies to analyze epidemiological knowledge, so that prevention and control measures can be adopted in a reasoned manner, thus contributing to improve the quality of life of patients and reduce the prevalence of these endemic diseases (Portella, 2002). The prevalence of acute and chronic forms does not match the actual prevalence in the population, due to the late discovery of viral infection, since these cases were diagnosed and already reported as chronic forms (Brazil, 2012).

In July 2014 the hepatitis A vaccine was introduced in the National Vaccination of the Unified Health System Calendar (SUS). Doses target children aged 12-23 months. The purpose is to prevent and control hepatitis A and thus gradually immunize the entire population. The vaccination schedule recommended by the National Immunization Program (NIP) of the Ministry of Health provides a single dose of vaccine. The epidemiological situation of the disease is monitored in order to determine whether or not to include a second dose in the child's schedule. It is estimated that with the hepatitis A vaccine, cases of jaundice decrease by $64 \%$, and deaths by $59 \%$ (Brazil, 2014). As for HCV, there is not a measure of immunoprophylaxis, and prevention should focus on counseling, especially for drug users and individuals with risky sexual 
practices (Ferreira et al., 2004).

The profile found in Maringá showed a higher incidence of hepatitis $C$ in males aged between 20 and 49 years.

Spatial analysis of health events is necessary in order to evaluate the risks to public health, particularly those related to the environment and the socioeconomic profile of the population (Bailey, 1995. The use of maps is essential to support the diagnosis and analysis of health problems, and to enable efficient deployment of the resources devoted to the implementation of sanitary practices in health administration. The geographical approach, applied to public-health issues, is important as itcomplements studies on pathological phenomena (Fonzar, 2008). Epidemiological studies that address the issue of the spatial distribution of all the major HBVs in populations are uncommon. The present study analyzed the clinical and epidemiological profile and the distribution of reported cases of hepatitis A, B and C in Maringá, state of Paraná, Brazil.

\section{Materials and Methods}

\section{Study area}

This cross-sectional study used a descriptive approach. The study area was the municipality of Maringá, situated at $23^{\circ} 42^{\prime} \mathrm{S}$, $51^{\circ} 93^{\prime} \mathrm{W}$, with a maximum elevation of $596 \mathrm{~m}$ above mean sea level, in North-western Paraná (Figure 1). The municipality is located $426 \mathrm{~km}$ from the state capital Curitiba, and $632 \mathrm{~km}$ from São Paulo. Maringá occupies an area of approximately $488 \mathrm{~km}^{2}$, and is divided into 53 census zones. The municipality has an urban population of 350,653 and 6,424 rural inhabitants. Currently, the modular growth follows the basic guidelines set out in the initial directive plan (Fonzar et al., 2012).

\section{Study subjects}

Data were gathered from the municipal Department of Epidemiology and Health Management, using the SINAN database. The study included reported cases of hepatitis A, B and C, from January 2007 through December 2010, for persons living in Maringá with laboratory serological confirmation of the virus. Subjects were excluded if the serology results were inconclusive or missing, and if the home address was not available. Variables of interest concerning the patients were analyzed, including the date of birth, sex, race, education level, comorbidities, vaccine-induced immunity, clinical status, final classification of the notification, institutionalization and death; time (date of notification) and place (street, house number, district and census zone).

\section{Mapping approach}

To map the data, we used the geographic information system (GIS), with the free geographic information processing system SPRING, version 5.1.8, developed by the National Institute for Space Research (INPE) (Câmara et al., 1996). The points recorded were entered into the database in order to map the distributionof the confirmed cases of hepatitis A, B and C. The base map was provided by the GIS Coordination of Urban Development Department Housing and the City of Maringá (SEDUH).

The geographical unit used was the IBGE census zones, as adopted by the Maringá City Hall. To show the spatial distribution of hepatitis A, B and C, we mapped the occurrences for each cen- sus zone. Then, the 53 census zones of the municipality were grouped into six categories, according to the income level of the residents, i.e. the mean monthly income of individuals ten years old or over (IBGE, 2010). To develop a heterogeneous classification of the census zones, we used the variables: income level, number of cases, and incidence.

\section{Statistics}

The statistical association between hepatitis A, B and C and the variables of interest were tested using the chi-square test $\left(\chi^{2}\right)$ and Fisher's Exact Test, with a 5\% significance level. Data were analyzed with Stata 9.0 program (Stata Corporation, College Station, TX, USA).

\section{Results}

From January 2007 through December 2010, 637 cases of hepatitis A, B and C were recorded in SINAN. Of these, 265 records that were classified as discarded and 24 cases with an inconclusive seropositivity test were excluded. The diagnosis was established by clinical and laboratory criteria. Of the serologically confirmed cases, one instance of hepatitis B and one case of hepatitis $\mathrm{C}$ were discarded because it was not possible to find the home address of the patients. The final total was 338 confirmed and geolocated monoinfected cases of either hepatitis A, B or C + four subjects with a coinfection with more than one type of viral hepatitis: one co-infection with hepatitis A and C, and three with hepatitis B and C. Of the 338 monoinfected cases, 5.6\% $(n=19)$ had hepatitis A, $44.7 \%(n=151)$ had $B$ and $49.7 \%(n=168)$ had $C$, with an incidence rate of 1.45 per 100,000 inhabitants for hepatitis $A$, and 11.09 and 12.17 reported per 100,000 inhabitants for hepatitis B and C, respectively. In terms of gender, the majority of the confirmed cases, $187(55.3 \%)$, occurred in males $(\mathrm{P}<0,01)$. In terms of age, the highest percentage of reported cases of hepatitis $\mathrm{B}$ and $\mathrm{C}$ was observed in individuals aged 20-49 years $(60,7 \%, n=205$, $\mathrm{P}<0,001)$. The predominant race was white, corresponding to 13 $(68.4 \%)$ cases of hepatitis A, $123(81.4 \%)$ of hepatitis B and 133 $(80.9 \%)$ of hepatitis C. Most of the patients had some eight years

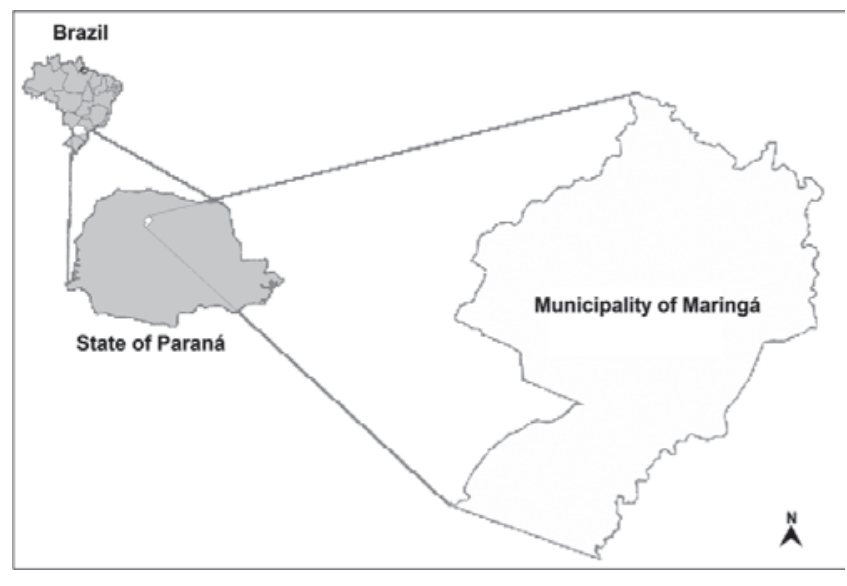

Figure 1. Location of Maringá in Paraná State, Brazil. 
of school $(92.3 \% ; \mathrm{n}=312, \mathrm{P}=0.0439)$ (Table 1$)$. To form the groups of areas, we included census zones where there were confirmed cases of the disease (Table 2; Figure 2A). Ten census zones (zones $2,3,8,11,15,17,24,25,38,43)$ had an incidence of hepatitis A of more than 9 cases per 100,000 residents. Thirty-seven $(69.8 \%)$ and $33(62.3 \%)$ census zones had cases of hepatitis B and C, respectively. Sixteen zones were excluded from the analysis because information on some variables was lacking.

In the analysis of the spatial distribution by income level and zone, cases were concentrated in area $2(n=21)$, where the residents have a mean monthly per capita income of R 500 to $\mathrm{R} \$ 1,000$ (around 150-300 USD). Based on the mean monthly income, we calculated the incidence and reported cases of viral hepatitis for the grouped census zones. Hepatitis A showed a low incidence (1.45 cases/100,000 population), with the highest number of reported casesof hepatitis B (11.09 cases/100,000 population) and C (12.17 cases/100,000 population) (Table 3 ). Of the 151 reported cases of hepatitis B, $26(17.2 \%)$ individuals were properly immunized with the vaccine against HBV. In 7 (4.6\%) individuals, vaccination was incomplete; 104 (68.9\%) were unvaccinated; for 14 (9.3\%) indi-

Table 1. Confirmed cases of viral hepatitis A, B and C by sex, age, race and education level in the municipality of Maringá, Paraná, Brazil 2007-2010.

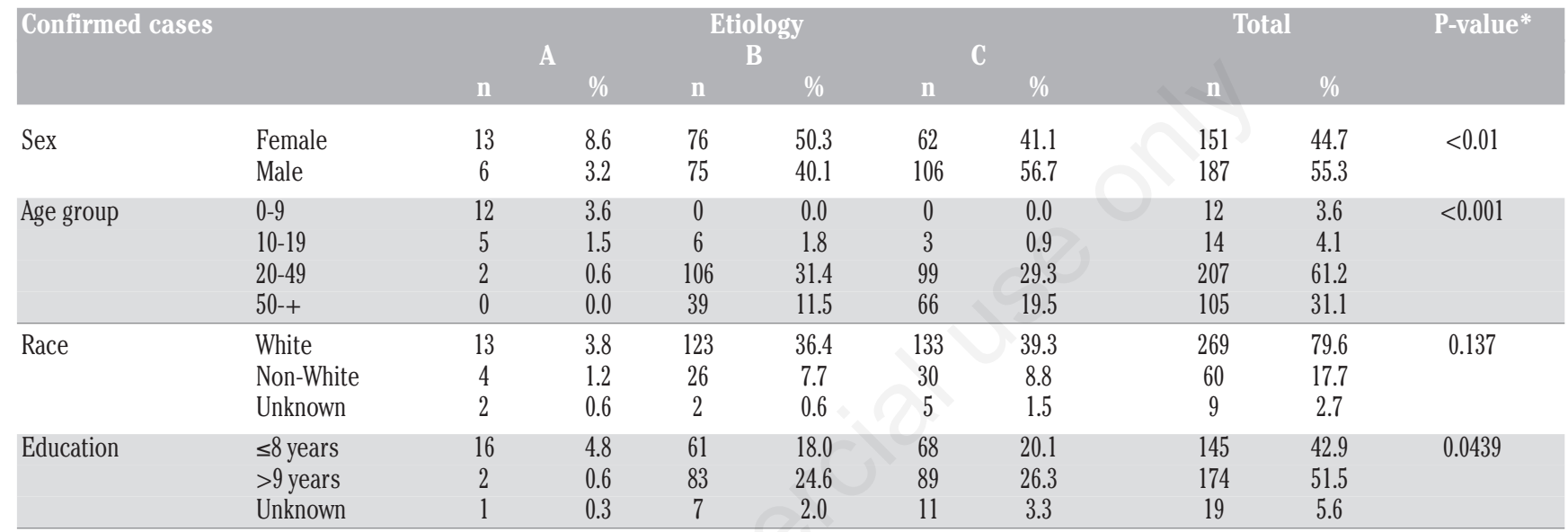

${ }^{*}$ Chi-square test $\left(\chi^{2}\right) ; \mathrm{P} \leq 0.05$

Table 2. Census zones in the study area grouped according to mean monthly income 2010 of individuals over 10 years of age in the municipality of Maringá, Paraná, Brazil.

\begin{tabular}{lcc} 
Area & Census zone & Mean monthly income (USD) \\
1 & 42 & $<150$ \\
2 & $6,12,18,19,22,23,24,25,30,31,33,34,36,37,38,39,41,43,45,46,47$ & 150 to 300 \\
\hline 3 & $3,8,11,13,14,15,21,26,29,35,44,48$ & 300 to 450 \\
4 & $7,9,10,17,20,27,28$ & 450 to 650 \\
\hline 5 & $2,4,5,40$ & 350 to 950 \\
6 & 1 & $>950$
\end{tabular}

Table 3. Incidence of hepatitis $A$ and reported cases of $B$ and $C$ per 100,000 inhabitants in areas with similar income levels in the municipality of Maringá, Paraná, 2010.

\begin{tabular}{|c|c|c|c|c|c|c|c|}
\hline \multirow[t]{2}{*}{ Areaa } & \multirow[t]{2}{*}{ Population } & \multicolumn{2}{|c|}{ Hepatitis A } & \multicolumn{2}{|c|}{ Hepatitis B } & \multicolumn{2}{|c|}{ Hepatitis C } \\
\hline & & n & $l^{b}$ & $\mathrm{n}$ & $\mathrm{RC}^{\mathrm{c}}$ & n & $\mathbf{R C}^{\mathrm{c}}$ \\
\hline 1 & 1,386 & 0 & 0.00 & 0 & 0.00 & 0.00 & 0.00 \\
\hline 2 & 189,805 & 11 & 1.45 & 92 & 12.12 & 116 & 15.28 \\
\hline 3 & 69,335 & 7 & 2.52 & 31 & 11.18 & 24 & 8.65 \\
\hline 4 & 57,004 & 1 & 0.44 & 16 & 7.02 & 17 & 7.46 \\
\hline 5 & 17,933 & 1 & 1.39 & 13 & 18.12 & 10 & 13.94 \\
\hline 6 & 10,946 & 0 & 0.00 & 1 & 2.28 & 1 & 2.28 \\
\hline Total & 346,409 & 20 & 1.45 & 153 & 11.09 & 168 & 12.17 \\
\hline
\end{tabular}

Adapted from IBGE, 2010;; areas as in Table 2; bIncidence; cReported cases. 
viduals this information was lacking. Of the 152 cases of hepatitis $\mathrm{A}, \mathrm{B}$ and $\mathrm{C}$ reported for females, $32(21.1 \%)$ were pregnant $(\mathrm{P}=0.0012)$. In addition, $25(78.1 \%)$ of the pregnant women were infected with the B virus and 6 (18.8\%) with C. One (3.1\%) had a co-infection with B and C, while $2(6.3 \%)$ were coinfected with $\mathrm{HCV}$ and the human immunodeficiency virus (HIV). Two $(6.3 \%)$ were in the first trimester of pregnancy, $15(46.9 \%)$ in the second and $15(46.9 \%)$ in the third. With respect to individual characteristics, $42(12.3 \%)$ were institutionalized at the time of notification $(\mathrm{P}<0.0001)$ in nursery $(\mathrm{n}=7)$, in school $(\mathrm{n}=4)$, in company $(\mathrm{n}=10)$, in prison $(n=6)$, in hospital $(n=7)$ or in othersimilar situation $(n=8)$. Of these, $10(23.8 \%)$ were infected with the A virus, $13(31.0 \%)$ with B and18 (42.9\%) with $\mathrm{C}$; one $(2.4 \%)$ showed a coinfection with viruses B and C.All cases of hepatitis A infection are acute. Of the B virus carriers, 17 (11.3\%) showed the acute form and 134 $(88.7 \%)$ had chronic disease. All patients $(n=168)$ with hepatitis C were chronic carriers of the virus. Of the 338 total cases, 47
(13.9\%) had comorbidities $(\mathrm{P}<0.0001): 31(65.9 \%)$ had a co-infection with HIV, and $16(34.1 \%)$ with other sexually transmitted infections (STIs). Fifteen (4.4\%) patients died during the study period, including $6(1.8 \%)$ due to chronic hepatitis C, $1(0.3 \%)$ due to hepatitis B, $2(0.6 \%)$ from cirrhosis of the liver and $1(0.3 \%)$ from complications of HIV/HCV co-infection. Two deaths $(0.6 \%)$ were byunknown causes, and $3(0.9 \%)$ died due to causes unrelated to hepatitis, i.e. acute myocardial infarction or renal failure.

Several cases appeared incensus zones 24, 36 and 37 (5.7\%), however, these zones have relatively large populations, 27,137, 32,687 and 22,078 inhabitants, respectively. Census zones 10, 13, $22,41,42,45,49,50,51$ and $53(21.1 \%)$ had no reported cases. In 2008 , four cases of hepatitis A were reported in zone 38. In 2009, there were no cases of hepatitis $\mathrm{A}$ in this zone. In addition, from 2007 to 2010, 11 cases ( 7 cases of hepatitis B and 4 cases of hepatitis C) were reported in the rural and urban districts (Figure 2BD). Regarding the distribution of hepatitis $\mathrm{C}$ in the municipality,
A

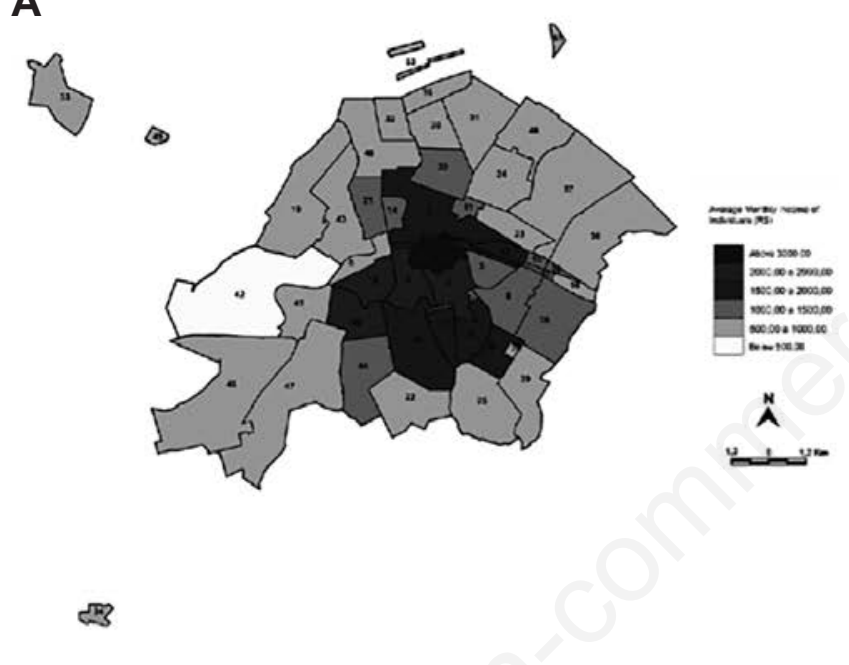

B

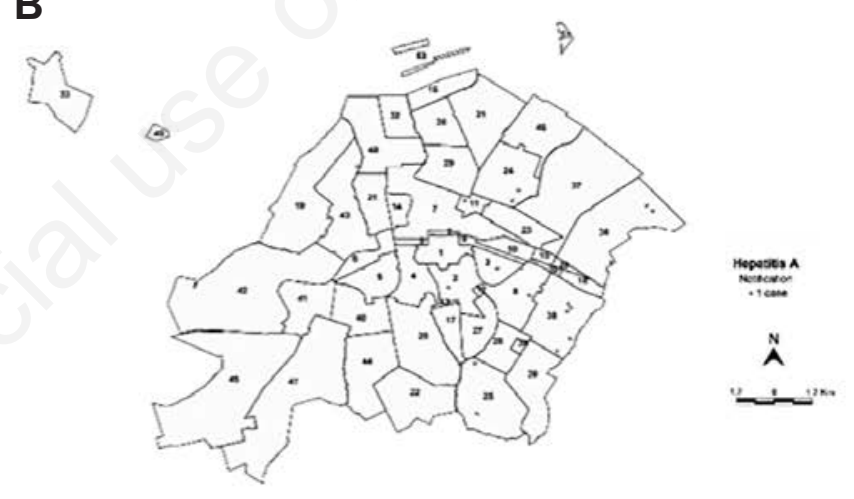

43

D

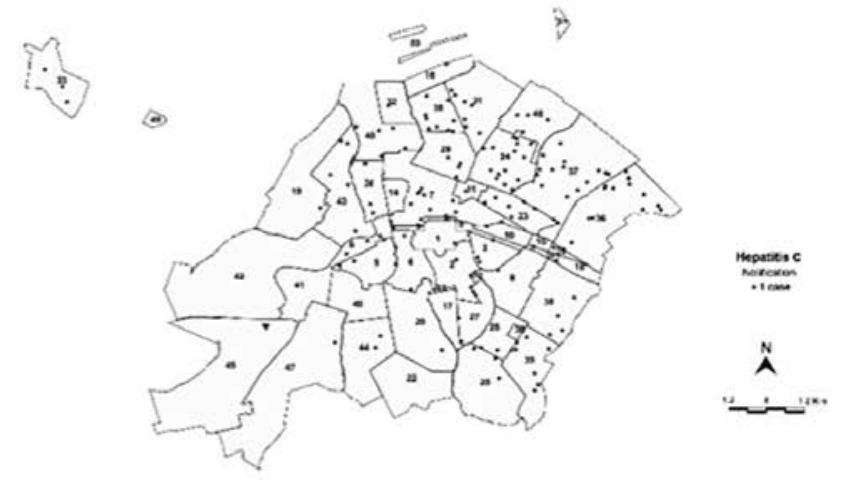

Figure 2. Spatial distribution of reported cases of viral hepatitis in the municipality of Maringá, Paraná, Brazil 2007-2010. A) Spatial distribution in areas with similar income levels; B) Spatial distribution of confirmed cases of viral hepatitis A; C) Spatial distribution of confirmed cases of viral hepatitis B; D) Spatial distribution of confirmed cases of viral hepatitis C. 
cases were concentrated in census zone $37(\mathrm{n}=18)$ followed by zone $24(\mathrm{n}=13)$. In addition, in 2009, there was a concentration of cases in zone $43(n=3)$, where the Maringá State Penitentiary (PEM) is located.

\section{Discussion}

In this study, the highest incidence of hepatitis A occurred in females aged 0-9 years, and declined in adulthood. This pattern is found in the general population of Brazil, in which the most affected age group is 5 to 6 years (Brazil, 2015). Of the 151 cases reported during the study period, the age group between 20 and 49 years was most affected by HBV $(\mathrm{P}<0.001)$. A survey of hepatitis $\mathrm{B}$ infection conducted in Brazil and the state of Santa Catarina, in the 1996-2002 period, detected aprevalence of hepatitis B in relation to other viral hepatitis strains in the 20-49-year age group (Chávez et al., 2003).

Hepatitis A virus (HAV) has a universal scope, and the disease is most prevalent in places with poor sanitary conditions, especially in underdeveloped or developing countries. The low incidence of HAV found in Maringá is a reflection of urban infrastructure indicators; $99.8 \%$ of households has piped water, $98.2 \%$ have garbage collection, $100 \%$ have electricity and $60 \%$ have sewage disposal (IBGE, 2010). The number of cases reported for hepatitis B was above that reported for Brazil as a whole in 2016 (detection rate of 6.9 cases $/ 100,000$ inhabitants), but below that for the South region (detection rate of 16.4 cases/100.00 inhabitants) and the State of Paraná (detection rate of 17.5 cases/100,000 inhabitants). For hepatitis $\mathrm{C}$, it was slightly above that reported for Brazil in 2016 (detection rate of 6.5 cases/100,000 inhabitants) and very close to that for the South region (detection rate of 12.0 cases/100,000 inhabitants) and above the State of Parana (rate of detection of 6.3 cases/100,000 inhabitants) (Brazil, 2017).

Sexual transmission of HBV is a common infection route, since in this age group, individuals are economically and sexually active, but outcomes vary. The sex ratio detected in Brazil for the B virus from 2004 to 2016, it was found that the female has a significantly earlier exposure to the HBV; however, the maximum exposure period is shorter than in men, which results in a lower total number of cases among women. These differences probably reflect different patterns of sexual behaviour between the sexes (Brazil, 2015). Similarly, the present study found statistically significant difference between the sexes $(\mathrm{P}=0.01)$, as found in a study conducted at the Clínica Municipal de Especialidades Médicas de São Bernardo do Campo-SP, where the sex ratio for HBV was 0.9 men for every woman (Pelegrini et al., 2007). In a study of patients seen at the Central Public Health Laboratory of Pará, from January 2002 through December 2005, the positivity rate for HBV for males was $62.6 \%(n=928)$, and for females was $37.4 \%(n=554)$. In this study, the number of confirmed cases of hepatitis B differed significantly between the sexes (Aquino et al., 2008). Published data indicate that the difference between the sexes appears to be related to increased susceptibility to acquiring the infection, but behavioural aspects such as drug use, promiscuity and failure to use condoms all increase the vulnerability (Pelegrini et al., 2007). Another important point is that many individuals trivialize the disease and do not consider it to be sexually transmitted.

A small proportion of patients diagnosed with HBV had completed the vaccination schedule, but more were unvaccinated. Among the cases of hepatitis $\mathrm{C}, 17.1 \%$ had completed the vaccina- tion for HBV, but the majority (67.4\%) were not vaccinated. Similar results were found by Cruz, Shiatsu and Martins (Cruz et al., 2009). Vaccination is the safest and most effective control and prevention measure, and has the greatest impact on hepatitis B. The initial response to the vaccine decreases with advancing age. In healthy children, adolescents and young adults (20-39 years), the protective response is generally greater than $90 \%$, falling to $70 \%$ in individuals aged 50-59 years, and around 50\% in adults over 60 years. Other factors that interfere with the immunogenicity of the vaccine include smoking, obesity, and immunosuppressive diseases, including diabetes mellitus, corticosteroid use, chronic renal failure, and HIV infection (Leroux-Roels et al., 1997; Resti et al., 1997). A proportion of healthy individuals can still be found, ranging from $2,5 \%-5.0 \%$, who did not respond satisfactorily to HBV vaccination and were considered non-responders to the hepatitis B vaccine (Desombere et al., 1995; Pillot et al., 1995). By the year 2010 in Brazil, the vaccine was included in the routine for children and adolescents younger than 20, and in 2011 this was extended to youths under 24 years old. In 2012, routine vaccination was extended to young people up to 29 years old, and in 2013 the age was extended to 49 years. Vaccination against hepatitis B is almost universal, since it is also recommended for prioritized groups at high risk of exposure or with greater vulnerability to transmission (Brazil, 2013).

The most affected age group was 45 to 54 years $(29.6 \%)$. However, when stratified according to sex, observed that infected men are younger than women.Among men, the majority of cases are among those aged 40 to 49 years $(32.3 \%)$, while the majority of women are 60 years of age or older (Brazil 2015). The finding of a significantly higher risk among men confirms observations made at different times and for different populations, allegedlyas a result of more-frequent risk behaviours in males, such as drug use, multiple partners and unprotected exposure to sexual contact (CDC, 1998; Brandão et al., 2002). The increase seen with age is associated with the populations where the most important transmission mechanisms involve behaviour throughout life, such as risky sexual activity, use of injected illicit drugs and other means of exposure to blood and blood products (Souza et al., 2004).

The prevalence of HBV and HCV in Brazil varies considerably according to demographic and socioeconomic characteristics of the local population. Northern Brazil has the highest endemicity (Ferreira et al., 2004). In Brazil, it is estimated that there are at least three million patients with chronic viral hepatitis (Araújo, 2004). The clinical presentation of hepatitis B in Maringá was characterized in $11.3 \%$ of confirmed cases of HBV as the acute form of the disease, and $88.7 \%$ as the chronic form. In relation to hepatitis $\mathrm{C}$, all patients were chronic carriers of the virus. These results are in agreement with the general Brazilian profile, in which the predominant clinical presentation of confirmed cases of hepatitis C between 1999 and 2010 was chronic in all of the age groups under consideration, and acute cases occurred in small proportions, especially in age groups under 12 years (Brazil, 2015). The prevalence of chronic forms (including cirrhosis) in Manaus was $81.5 \%$ for hepatitis B and $70.5 \%$ for hepatitis C (Araújo, 2004). Another important issue is that of the 338 cases examined in this study, $13.9 \%(n=47)$ had comorbidities. This is consistent with an epidemiological study of 401 patients infected with human immunodeficiency virus, treated at the Hospital das Clínicas of the Faculty of Medicine, University of São Paulo, Ribeirão Preto (Souza et al., 2004). A study conducted at the Clínica Municipal de Especialidades Médicas de São Bernardo do Campo-SP, analyzed 
613 records of patients with confirmed notification of hepatitis B and/or C. Of these, $120(19.6 \%)$ had an HBV infection, 397 (64.8\%) had HCV and 96 (15.6\%) had a coinfection with HBV and $\mathrm{HCV}$. The simultaneous presence of hepatitis B and C markers occurred in 81 (20.4\%) individuals of the 398 for whom there were results for both infections (Pelegrini et al., 2007). Coinfections in patients with $\mathrm{HBV} / \mathrm{HCV} / \mathrm{HIV}$ occur in considerable numbers, and are explained by the common routes of transmission of these viruses, sexual, parenteral and vertical (Souza et al., 2007).

Pregnancy showed a positive association with hepatitis A, B and $\mathrm{C}$. This creates challenges to public health, such as planning comprehensive and practical screening strategies to facilitate the clinical management of pregnant women diagnosed with hepatitis (Figueiro-Filho et al., 2007). The neonatal hepatitis infection B increases risk of disease chronicity and evolution for cirrhosis and hepatocarcinoma (Xiao et al., 2007), and the persistent prevalence of infection among the population, is extremely important to perform serology screening in prenatal care in order to initiate treatment early, or even avoid vertical transmission (Piazza, 2010). Currently, to prevent vertical transmission of HBV from the positive mother to the newborn, shortly after birth the neonate received one dose of vaccine and anti-HBV immunoglobulin (Secretaria de Estado da Saúde de São Paulo, 2002). Due to the risk of infection at birth, regardless of the mother's HIV status, a dose of vaccine to all infants during the first 12 hours of lifeis recommended. The vertical vaccine prevents infection in $90 \%$ of cases, besides enabling breastfeeding without the risk of HBV infection (Secretaria de Estado da Saúde de São Paulo, 2002). In our study, immunoglobulin was administered to $96 \%(n=24)$ of infants during the first 12 hours of life. In one case, it was not possible to administer the prophylaxis because the infant died soon after birth.

The spatial-distribution maps of the places of residence of the carriers of viruses A, B and C in 53 census zones of the municipality of Maringá, showed a heterogeneous distribution of these infections, both in central areas and in areas near the periphery of the urban area. The case distribution pattern in the urban area showed a higher concentration of cases in the northern part of the municipality, which is probably associated with the population density, as assessed in zones 24, 36 and 37, which are the most populous. In the northern part of the municipality, the urban fabric is denser, with a larger built area and aconcentration of housing with average- and low-income households. In this part, the urban area of the municipality is expanding (Fonzar, 2012). In the southern part of the municipality, there is a higher concentration of industry and a lower population density, hence with fewer reported cases of viral hepatitis.

In 2008, there was a concentration of reported cases of hepatitis A in zone 38, as a result of an outbreak in a nursery. Daycare centers and schools are an important source of enteric virus transmission (Villar et al., 2002). As seen in this study, institutionalized individuals had a significantly greater association with hepatitis $\mathrm{A}$, $\mathrm{B}$ and $\mathrm{C}(\mathrm{P}<0.0001)$.

Regarding hepatitis B, starting in 2008, notification was initiated in both the rural and urban districts of the municipality. The location of these cases could be determined from the house address of individuals on the main rural roads. In addition, some domestic cases were concentrated in the town, as occurred in census zone 19, in 2009. Close contact between residents of the same household and the common use of personal items such as toothbrushes and razor blades are possible transmission routes (Kim et al., 1993).
Regarding the distribution of hepatitis $\mathrm{C}$ in the municipality, in 2008 and 2009 there was a concentration of cases in zones 37 and 36 , respectively. In these zones, the monthly income ranges from 500 to 1000 Brazilian Reals (about 150-300 USD) and the population is 32,687 and 27,137 inhabitants, respectively. Four cases of hepatitis $C$ were concentrated in zone 45 , where the municipal prison is located. The prison population is considered at high risk for several infections such as tuberculosis, HIV, hepatitis B, hepatitis $\mathrm{C}$ and STIs in general, since the social marginalization, dependence on illicit drugs, low socioeconomic status, and poor health-system conditions facilitate the spread of these diseases among prisoners (Coelho et al., 2009; Massad, 1997).

The incidence of hepatitis A, B and C in Maringá is consistent with epidemiological data for Brazil as a whole. Some limitations of this type of study indicate the need for caution in evaluating the results (Ferreira, 2004). Information regardingall hepatitis infections in this study were obtained from the SINAN, howeverthe number of notifications may not reflect the actual incidence of infection, as the vast majority of affected persons have asymptomatic or oligosymptomatic forms of hepatitis, which are seldom identified (Figueiro-Filho et al., 2007). Another issue that limits the analysis of the data is that the notification of hepatitis is still incomplete, due to the large amount of unknown epidemiological data, as well as incomplete reporting forms. It is possible that the total number of cases reported in this study underscoresthe real situation, since even in countries where the disease is notifiable, it is estimated that substantial under reporting of cases occurs (Martelli et al., 1990). The number of asymptomatic infections is significant, and this leads to wider dissemination in the community than is indicated by the appearance of clinical cases (Miranda et al., 2000).

\section{Conclusions}

The spatial distribution of cases of viral hepatitis in the municipality was heterogeneous, and did not indicate any area with a higher risk of viral infection, although the northern area deserves more attention, as well as the people who are institutionalized. Because hepatitis is a chronic disease, the four-year historical series did not show a pattern of increasing or decreasing occurrence. In spite of the existence of gaps, these results can provide useful information for the development of strategies used in the epidemiological surveillance service, for the prevention and control of viral hepatitis in the municipality, especially for the prenatal program performed during pregnancy play an important role in the diagnosis and prevention of the spread of these infections. In addition to evidence of late diagnosis in the second and third trimester of gestation.

\section{References}

Aquino JA, Pegado KA, Barros LP, Machado LFA, 2008. Seroprevalence of hepatitis B virus and hepatitis C virus infections among individuals in the State of Pará. Rev Soc Bras Med Trop 41:334-7.

Araújo A, 2004. Hepatites B e C em Manaus: perfilclínico-epidemiológico e distribuiçãoespacial de casosconhecidosdesde 1997 a 2001. Fundação Oswaldo Cruz. EscolaNacional de 
SaúdePública/Universidade Federal do Amazonas.

Bailey TC, Gatrell AC. Interactive spatial data analysis. Harlow: Longman; 1995.

Brandão ABM, Fuchs SC, 2002. Risk factors for hepatitis C virus infection among blood donors in southern Brazil: a case-control study. BMC Gastroenterol 2:18.

Brazil, Ministério da Saúde, Secretaria de VigilânciaemSaúde B, 2014. Vacina contra hepatite A passa a seroferecidapelo SUS Ministério da Saúde-Dep. DST, Aids e HepatitesVirais.

Brazil, Ministério da Saúde, Secretaria de VigilânciaemSaúde B, 2012. Ampliação da faixaetária para a vacinação contra hepatiteBemobilização social nacional. Ministério da SaúdeDep. DST, Aids e HepatitesVirais.

Brazil, BoletimEpidemiológicoHepatitesVirais, 2015.

Brazil, 2017. BoletimEpidemiológicoSecretaria de VigilânciaemSaúde. Ministério da Saúde 48.

Câmara G, Souza R, Freitas U, Garrido J, 1996. Spring: integrating remote sensing and gis by object- oriented data modelling. Comput Graph 2:395-403.

Centers for Disease Control and Prevention, 1998. Recommendations for prevention and control of hepatitis $\mathrm{C}$ virus (HCV) infection and $\mathrm{HCV}$-related chronic disease. MMWR Recomm Rep 47:1-39.

Chávez JH, Campana SG, Haas P, 2003. An overview of hepatitis $\mathrm{B}$ in Brazil and in the state of Santa Catarina. Rev Panam Saludpública 14:91-6.

Coelho HC, Lourdes M De, Oliveira A, Dinis A, Passos C, 2009. Soroprevalência da infecçãopelovírus da Hepatite B emumaprisãobrasileira [Seroprevalence of Hepatitis B vírus infection in a Brazilian jail]. Rev Bras Epidemiol 12:124-31.

Cruz CRB, Shirassu MM, Martins W, 2009. Comparison between hepatitis $\mathrm{B}$ and $\mathrm{C}$ epidemiological profiles at a public institution in São Paulo, Brazil. Arq Gastroenterol 46:225-9.

Desombere I, Hauser P, Rossau R, Paradijs J, Leroux-Roels G, 1995. Nonresponders to hepatitis B vaccine can present envelope particles to T lymphocytes. J Immunol 154:520-9.

Ferreira CT, Silveira TR, 2004. Hepatitesvirais: aspectos da epidemiologia e da preven. Rev Bras Epidemiol 7:473-87.

Figueiro-Filho EA, Senefonte FR, Lopes AH, de Morais OO, Souza Junior VG, Maia TL, 2007. Frequency of HIV-1, rubella, syphilis, toxoplasmosis, cytomegalovirus, simple herpes virus, hepatitis B, hepatitis C, Chagas disease and HTLV I/II infection in pregnant women of State of MatoGrosso do Sul Rev Soc Bras Med Trop 40:181-7.

Fonzar UJV, Langoni H, 2012. Geographic analysis on the occurrence of human and canine leptospirosis in the city of Maringá, state of Paraná, Brazil. Rev Soc Bras Med Trop 45:100.

Fonzar UJV, 2008. Análise espacial da mortalidade por causas externas no município de Maringá, Estado do Paraná, 1999 a 2001. Acta Sci Heal Sci 30:145-54.

Instituto Brasileiro de Geografia e Estatística, 2017. Projeção da população do Brasil e das Unidades da Federação.

Instituto Brasileiro de Geografia e Estatística. 2010 Censodemográfico.

Kim YS, Ahn YO, 1993. Factors associated with intrafamilial transmission of hepatitis B virus infection in Korea. J Korean Med Sci 8:395.

Leroux-Roels G, Desombere I, Cobbaut L, Petit M-A, Desmons P, Hauser P, 1997. Hepatitis B vaccine containing surface antigen and selected preS1 and preS2 sequences 2 . Immunogenicity in poor responders to hepatitis B vaccines. Vaccine 15:1732-6.

Martelli CM, de Andrade AL, Cardoso D das D, Sousa LC, Almeida Silva S, de Sousa MA, 1990. Seroprevalence and risk factors for hepatitis B virus infection by AgHBs and anti-HBs markers in prisoners and prime blood donors. Rev Saúde Pública 24:270-6.

Massad E, 1997. HIV/AIDS no sistemaprisionalbrasileiro. A epidemia de AIDS no Brasil: Situações e Tendências. Brasil: Ministério da Saúde; pp 142.

Ministério da Saúde-Secretaria de VigilânciaemSaúde B, 2013. Nota Técnicaconjunta nº2/2013/CGPNI/DEVEP E CGDHRV/DST-AIDS/SVS/MS. Ampliação da oferta da vacinahepatite B para a faixaetária de 30 a 49 anosem 2013. Ministério da Saúde-Dep. DST, Aids e HepatitesVirais.

Miranda LV, Passos AD, Figueiredo JF, Gaspar AM, Yoshida CF, 2000. Serological markers of hepatitis B in people submitted to blood testing in health care clinics. Rev Saúdepública 34:28691.

Pelegrini A, Barbanera EB, Gonçalves F, 2007. Incidência da infeccção e de fatores de risco para osvírus das hepatites B e C emdiferentespopulações e aassociação com diagnósticosorológico, bioquímico e molecular. Rev Panam Infectol 9:32-8.

Perim EB, Passos ADC, 2005. Hepatite B emgestantesatendidaspeloPrograma do Pré-Natal da Secretaria Municipal de Saúde de RibeirãoPreto, Brasil: prevalência da infecção e cuidadosprestadosaosrecém-nascidos. Rev Bras Epidemiol 8:272-81.

Piazza MJ, 2010. Hepatitesvirais e gestação 15:12-8.

Pillot J, Poynard T, Elias A, Maillard J, Lazizi Y, Brancer M, 1995. Weak immunogenicity of the preS2 sequence and lack of circumventing effect on the unresponsiveness to the hepatitis B virus vaccine. Vaccine 13:289-94.

Portella F, 2002. Impacto das Hepatites B e C no Brasil. Buscando a melhor chance de cura para a hepatitecrônica. V Sem do Aparel Dig. Rio de Janeiro RJ.

Resti M, Azzari C, Mannelli F, Rossi ME, Lionetti P, Vierucci A, 1997. Ten-year follow-up study of neonatal hepatitis B immunization: are booster injections indicated? Vaccine 15:1338-40.

Secretaria de Estado da Saúde de São Paulo, 2002. Guia de OrientaçõesTécnicasHepatites B e C.

Skaba DA, Carvalho MS, Barcellos C, Martins PC, Terron SL, 2004. Geoprocessing of health data: treatment of information on addresses. Cad Saúdepública 20:1753-6.

Souza MG de, Passos ADC, Machado AA, Figueiredo JF de C, Esmeraldino LE, 2004. HIV and hepatitis B virus co-infection: prevalence and risk factors. Rev Soc Bras Med Trop 37:391-5.

Souza DER, Panizzi M, Cavalcanti L, Dal'ri T, 2007. Incidência de hepatite Bevacinação no Estado de Santa Catarina. Brasil Arq Catar Med 36:50-4.

Villar LM, Esteves da Costa M do C, de Paula VS, Gaspar AMC. 2002. Hepatitis a outbreak in a public school in Rio de Janeiro, Brazil. Memórias do Inst Oswaldo Cruz 97:301-5.

World Health Organization, 2017. Global hepatitis report 2017.

Xiao XM, Li AZ, Chen X, Zhu YK, Miao J, 2007. Prevention of vertical hepatitis B transmission by hepatitis B immunoglobulin in the third trimester of pregnancy. Int $\mathrm{J}$ Gynecol Obstet 96:167-70. 